\title{
Strengthening Management of BUMDes to Increase Income and Welfare of Hendrosari Village, Menganti District, Gresik Regency
}

\author{
Author \\ Aries Kurniawan (Orcid ID. 0000-0003-1788-7974), Beni Dwi Komara (Orcid ID. 0000-0003-4952-5118), \\ Muhammad Ghufran Ramdhani (Orcid ID. 0000-0001-9983-8951), Ragillia (Orcid ID. 0000-0003-9983-8951)
}

\author{
Correspondence \\ Universitas Muhammadiyah Gresik. \\ ariesaja@umg.ac.id, benikomara@umg.ac.id, danirambo89@gmail.com, \\ putriragil1992@gmail.com
}

\begin{abstract}
:
In the PKM program, our partner is the Potential Development of Hendrosari Village, Menganti District, Gresik Regency. The location of this village is close to Benowo District, Surabaya City, East Java Province. This village has the potential to strengthen management in the management of Tourism Villages and the results of products managed by the Village Owned Enterprises. This tourism village is located on village land with an area of around 10 hectares with the potential for nature tourism with the concept of education.

Based on the results of interviews and observations there are two problems faced by partners, 1) The lack of optimal management of Village-Owned Enterprises (BUMDEs) that manage Eduwisata. 2) Lack of knowledge and community participation to develop the potential of the village and Lontar Sewu tourism.

Some of the things planned by the PKM team are to streghten management BUMDes by holding seminars and workshops to improve the knowledge and abilities of the Hendrosari Village community in general and the BUMDes management in particular. The purpose of this activity is to improve capabilities that have an impact on good business management and increase of capabilities BUMDes management, community and village income.

This activity was realized with an approach in the form of making a sustainable cooperation program until the end of PKM, creating a family atmosphere between the two and understanding that the problems experienced were a shared problem so that they could be solved together according to the level of responsibility to achieve the expected benefits, namely increased yields, production and productivity and competitiveness, independence and welfare of the community.
\end{abstract}

Keywords: BUMDes, Management, Income, Competitiveness and Welfare.

Received: 09 March 2020. Accepted: 03 August 2020

\section{Introduction}

Hendrosari village is located in the Menganti District area of Gresik Regency with a position limited by the territory of neighboring villages. In the north it is bordered by Pandu Village in Cerme Subdistrict, in the West it is bordered by Cerme Village in Cerme Subdistrict In the South it is bordered by Boboh Village in Menganti District, while in the east it is bordered by Kepatihan Village in Menganti District. The distance from Hendrosari Village to the subdistrict capital is $4 \mathrm{~km}$, which can be reached in about 0.20 hours while the distance to the regency capital is $14 \mathrm{~km}$, which can be taken in about 0.75 hours.

The area of Hendrosari Village is 192 hectares, which is administratively divided into 2 hamlets namely Hendrosalam and Hendrosari. The division of land in the village of Hendrosari is predominantly on the Siwalan Tree Farm and Rice crops in the rainy season while Corn and Polowijo in the dry season.
This village is famous for its main crops rarely found in other regions, namely Trees Siwalan This tree produces two natural products, the first is Legen and the second is Siwalan Fruit. Original Legen produced by siwalan tree in Hendrosari Village has an extraordinary function for health because it can treat various diseases, including: Kidney stones, Urinary tract pain, Back / waist pain due to being too tired / irregular in consuming rinking water .

BUMDesa Hendrosari was established in 2016 with Village Capital Participation from the Village Fund of Rp. 30,000,000, - With the Online Savings and Loans \& Payment Unit. And for 2017 there is an additional capital of Rp. 30,000 .000.

At present, waste management and business activity development in the service sector. With a population of 3,165 people, it is potential to develop other business activities, especially in the service sector. Among them are payment services for water and electricity bills. Fields can be carried out besides the savings and loan field. 
The development of another line of business carried out is the Lontar Sewu Tourism Village. This field is realized in the collaboration of Hendrosari Village with the Ministry of Village through the 2019 Local Economic Development Village Incubation Pilot Program.

The funds disbursed by the Ministry of Villages, Disadvantaged Regions and Transmigration reached Rp.1.3 billion. This fund was added with assistance funds from the APBDes of Rp.300 million.

This program certainly opens opportunities for increased economic and entrepreneurial activity in the village. Automatically, village land can develop the potential as a source of income to increase village income.

During this time the economic and entrepreneurial movement of Lontar Sewu Village in the field of selling legens and culinary preparations made from chicken. For income legen taker can reach Rp.5 million to Rp. 10 million per month. With an average sales of legens which reach Rp.200 thousand to Rp.300 thousand per day. With a selling price of Rp.10 thousand to Rp.20 thousand per liter.

Opportunities for people who earn income in this field are only for farmers who have siwalan plants. In fact, siwalan plants are not easy to develop like other types of plants. Because, these plants usually naturally grow by themselves.

The second is in the culinary field. Processed chicken dishes in the village of Hendrosari are already famous. Grilled chicken with a selling price of Rp.125 thousand per head is a superior product.

However, these have not been able to provide an optimal impact on village income. In fact, some of the Village Owned Enterprises that

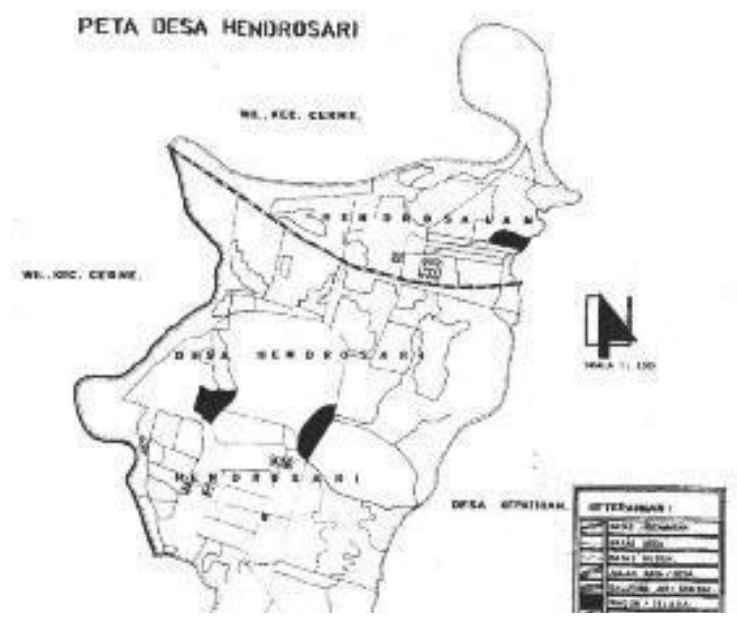

have been running are still experiencing problems to be able to have an optimal impact on village development and village income contribution.

Community waste management, for example, until now has not been able to contribute to community income.

Likewise for other superior products such as siwalan or legen produced by Village-Owned Enterprises.

The following are the fields of business that have been running in the village of Hendrosari:

Table 1. Some Industries Village

\begin{tabular}{|c|c|c|}
\hline \multicolumn{2}{|c|}{ Industrial Name } & \multirow{2}{*}{$\begin{array}{l}\text { Production result } \\
\text { Grilled chicken }\end{array}$} \\
\hline 1. & $\begin{array}{l}\text { RM Lesehan Berkah } \\
\text { Ilaahi }\end{array}$ & \\
\hline 2. & $\begin{array}{l}\text { Rumah Makan Pak } \\
\text { Wito }\end{array}$ & Grilled chicken \\
\hline 3. & $\begin{array}{l}\text { Depot Ayam } \\
\text { Panggang Ibu Hj. } \\
\text { Suminah }\end{array}$ & Grilled chicken \\
\hline 4. & $\begin{array}{l}\text { RM Dua Siwalan } \\
\text { Cak Pa'i }\end{array}$ & Grilled chicken \\
\hline 5. & Warung RD & Fried Eel, Fried Catfish \\
\hline & $\begin{array}{l}\text { Pecel Belut Pak } \\
\text { Hari }\end{array}$ & Fried Eel, Fried Catfish \\
\hline 7. & $\begin{array}{l}\text { Warung } \\
\text { Cak Dul dan } \\
\text { Bu Tutut }\end{array}$ & Fried Eel, Fried Catfish \\
\hline 8. & $\begin{array}{l}\text { Legen Asli } \\
\text { Cak Lim }\end{array}$ & Legen \\
\hline 9. & $\begin{array}{l}\text { LLegen } \\
\text { Asli Pak }\end{array}$ & Legen \\
\hline & $\begin{array}{l}\text { Legen Asli } \\
\text { Pak Juli }\end{array}$ & Legen \\
\hline 11. & $\begin{array}{l}\text { Rumah } \\
\text { Makan Sari } \\
\text { Legen }\end{array}$ & Legen \\
\hline & $\begin{array}{l}\text { Legen } \\
\text { Siwalan H. } \\
\text { Ponnadhir }\end{array}$ & Legen \\
\hline
\end{tabular}

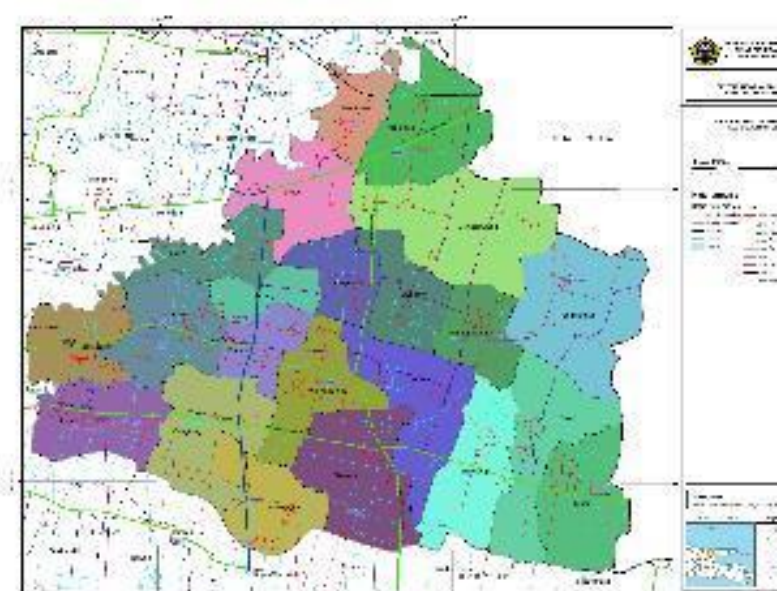

Figure 1. Location Map and Topographic Profile of Hendrosari Vilage 

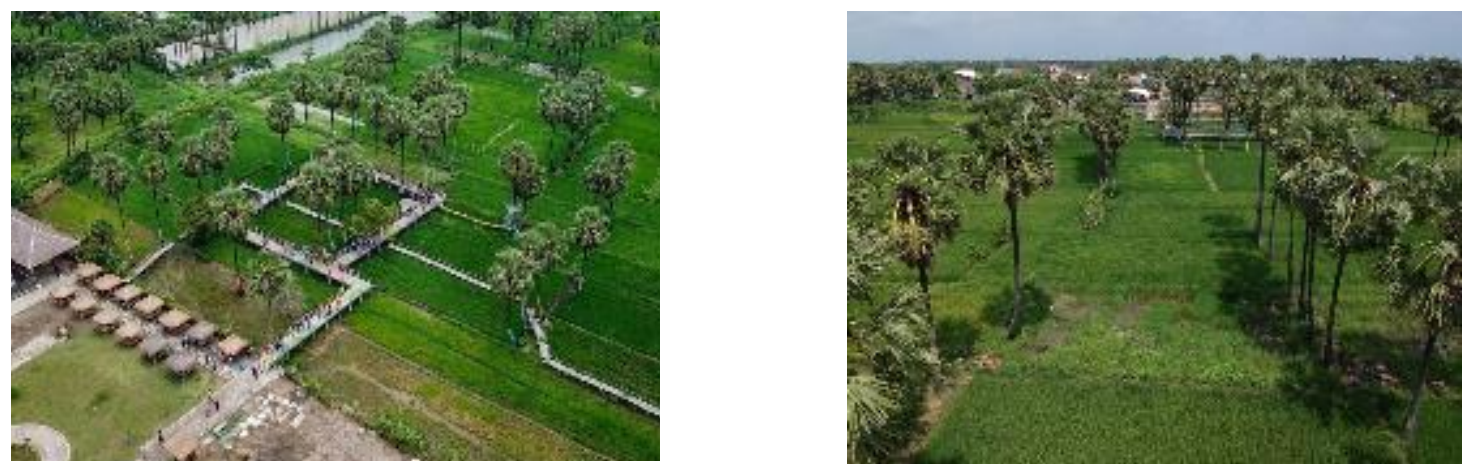

Figure 2. Potential Conditions in Hendrosari Village for Tourism

The opportunity to develop Hendrosari village, especially in the tourism sector with an area of about 10 hectares by making rides for selfie areas and playgrounds for children. In addition, the creation of a system for the implementation of the village tourism program and management improvement in its management needs to be carried out for the implementation of Lontar Sewu educational tour activities.

This is a step to increase the economic level of the Hendrosari village community and the income of the Hendrosari village. Thus this will provide optimal results both for villagers and the village government itself.

As a result, there has been an increase in community income with the realization of Education and strengthening knowledge about business and management. The number of visitors reached 3,000 visitors with revenues from parking around Rp.7 million to Rp. 10 million. Not only that, the community can sell their local products to visitors who attend. Culinary entrepreneurs who have long run their businesses also enjoy increasing income because of the large number of visitors at the Lontar Sewu site.

Therefore, it is necessary to design a tool with the application of ergonomics because ergonomics is a science that examines limitations, strengths, and human characteristics by utilizing information to design products, machines, facilities, environment, and even work systems in order to achieve the best quality work without ignoring health, safety, and human comfort aspects of its users (Sumardi, 2015).

The benefits of implementing ergonomics are reducing work accidents and work-related morbidity, reducing medical costs, compensation and stress, improving productivity and work flow and creating a sense of security because they are free from injury and increased job satisfaction (Sulaiman and Sari, 2018).
From the description of the condition of Hendrosari Village, it is concluded that there is potential for land that can be developed for tourism. But there needs to be an increase in management knowledge and management skills so that education can run well and optimally (Sulistiyani dan Rosidah, 2009 : 220).

\section{Method}

The implementation method is the description of the stages in applying the solutions that have been offered to overcome the edupreneur Lontar Sewu problem in Hendrosari Village, as follows:

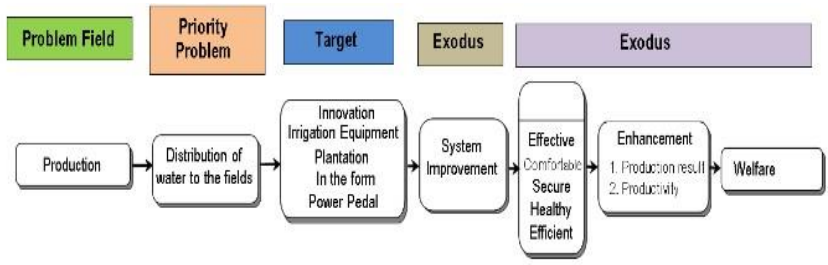

Figure 3. Steps in Implementing Solutions to Partner Problems in the Field of Management

\section{Results and Discussion}

Of all the proposed activities, used to determine the solutions and target outputs to be achieved, with the hope that will affect the increase in productivity, yields and competitiveness to meet market demand, and the realization of an effective, efficient and competitive business.

\section{- PKM Program Activities}

\section{Location of Activities or Partner Activities}

The activities or activities of partners so far have been carried out in Hendrosari village Menganti District area of Gresik Regency. 

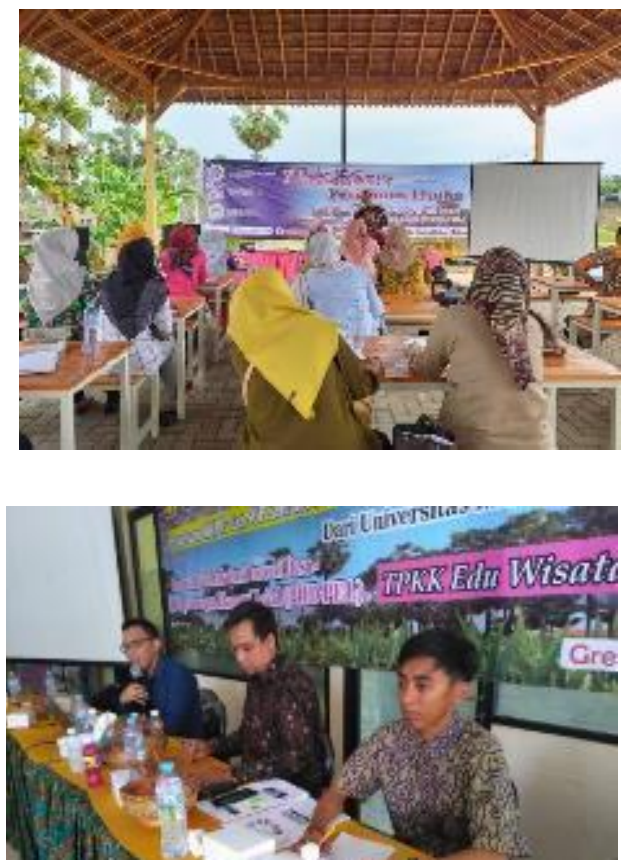

Figure 4 Strengthening Managerial Knowledge and Skills

Together with partners, the servants carried out several activities including:

a. Seminar, which is a meeting conducted by a group of people with the aim to discuss a particular topic and find solutions to problems by way of question and answer interaction. The goal is to increase knowledge about management, namely business management.

b. Workshop; that is, a single educational program, to teach or introduce each participant with practical, technical, or ideas that can be used in their work in their daily lives.

From the results of the activity, it can be concluded that the community and managers of BUMDesa do not have sufficient expertise to be able to optimize the business they run. They have not been able to carry out business with the optimization of existing potential.

Furthermore, the mindset and capabilities of the community and managers of BUMDesa have changed and improved. They can already understand to be able to optimize the existing potential. BUMDesa with the encouragement of the Village Government has collaborated in the program with the Ministry of Villages in the Local Economic Development Village Incubation Pilot Program in 2019.

The funds disbursed reached Rp.1,3 billion from the Ministry of Villages, Development of Disadvantaged Regions, and Transmigration of the Republic of Indonesia. This is coupled with assistance funds from the village budget of Rp.300 million.

\section{Condition of Lontar Sewu Tourist Village}

The estate located in front of Hendrosari lake with an area of $2.411 \mathrm{~m}^{2}$ on the land of the Gresik Government.

In addition, a variety of cheap tours can be enjoyed by visitors ranging from, water tourism, children's playgrounds, unique home gardens, palm selfie spots, legen water harvesting, culinary snacks, and family leisure area facilities.

Hendrosari Tourism Village also offers culinary specials of grilled chicken, grilled fish, and legen drinks that can be enjoyed by visitors with family during the weekend holidays. Hendrosari village is located on Jalan Hendrosari, Menganti District, Gresik Regency. Various restaurants and depots and food stalls typical of Hendrosari become the choice of visitors who want culinary with family.

\section{Description of Science and Technology to Be Implemented at Partners}

The following is a description of science and technology that will be implemented on partners;

a. The form of business entity uses the form of legal entity BUMDesa in accordance with the legal basis of Regulation of the Minister of Villages, Development of Disadvantaged Regions and Transmigration of the Republic of Indonesia Number 4 of 2015 concerning Establishment, Management and Management, and Dissolution of Village-Owned Enterprises

b. Knowledge and ability in the field of management can be applied to the development of BUMDes that manage the Lontar Sewu Field Trip. The planning, organizing, actuating and controlling system can be implemented so that the Lontar Sewu Eduwisata activities can run well.

c. Marketing and branding educational tour Lontar Sewu applies marketing management theory.

d. Employee recruitment applies the theory of human resource management.

e. The calculation of operating costs and revenues obtained applies the theory of financial management and operational management.

f. Measuring and increasing employee productivity using performance management theory.

g. The use of computer technology for the calculation of tourists who are present at the Lontar Sewu tourism site. This can be explained in Figure 5 below: 


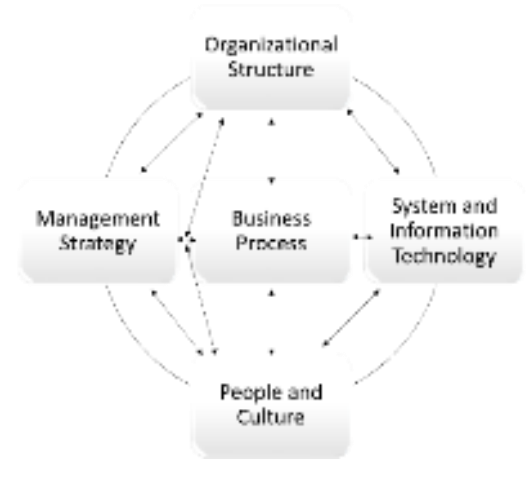

Figure 5. Overview of Science and Technology to Be Implemented in Partners

\section{Conclusion}

convey are:

Some conclusions that the author can

1. The problem in the field of production was solved by innovating service and product BUMDesa by managing the Lontar Sewu field trip.

2. For the solution of the problems in the field of management is to provide training and assistance related to business management and increase the ability to manage businesses and develop products and services that are appropriate to support the economic activities of Lontar Sewu Educational Tourism.

3. The two solutions above will be implemented by the PKM Grant Team during the Training and Mentoring event with a theme "Application of Strengthening Management of BUMDes to Increase Income and Welfare of Hendrosari Village, Menganti District, Gresik Regency", in February 2020.

4. The publication of the event was carried out on Instagram and Facebook as one of the outcomes that the PKM Grant Team had promised when submitting the proposal.

\section{References}

Edutivia. 2017. Peningkatan Pengetahuan dan Minat Berwirausaha Pada Industri Kreatif di Kecamatan Pemulutan Ogan Ilir, Jurnal Pemberdayaan Masyarakat Madani (JPMM), Vol.1 No. 2

Frandky Selamet, Hetty Kurnia Tanjung dan Mei Le. 2016. Dasar-Dasar Kewirausahaan: Teori dan Praktik. PT. Indeks. Jakarta.

Kurniawan, A .2018. Start, Run And Grow BUMDesa. UMG Press, Gresik

Kurniawan, A., Farida, Y. 2019. Alasan Warga Daerah Agraris Menjalankan Bisnis. Jurnal Riset Entrepreneurship. 2(1), 27-32.

Komara, BD. 2019. Manajemen Diri. UMG Press. Gresik.

Profil Desa Hendrosari. Available from: https://hendrosaridesaid.wordpress.com/poten si-desa/Diakses 27 Oktober 2019.
Subekti Ridhotullah dan Muhammad Jauhar. 2015. Pengantar Manajemen. Prestasi Pustaka. Jakarta.

Sukaris. 2019. Never Give Up! (Successful business of people with disabilities), Advances in

Economics, Business and Management Research, volume 88.

Sulaiman, F., \& Sari, Y. P. 2018. Analisis Postur Kerja Pekerja Proses Pengesahan Batu Akik dengan Menggunakan Metode Reba. Jurnal Teknovasi: Jurnal Teknik dan Inovasi, 3(1), 16-25.

Sumardi, A. 2015. Perbaikan Sistem Kerja Dengan Pendekatan Ergonomi Total Guna Peningkatan Kenyamanan Pekerja (Studi Kasus di UKM Genteng Press SK 2, Godean KM 11, Sleman). Tesis, UPN" Veteran" Yogyakarta.

Sulaiman, F., \& Sari, Y. P. 2018. Analisis Postur Kerja Pekerja Proses Pengesahan Batu Akik dengan Menggunakan Metode Reba. Jurnal Teknovasi: Jurnal Teknik dan Inovasi,

3(1), 16-25.

Yuswohady. 2014. Marketing To The Middle Class Muslim. PT. Gramedia Pustaka Utama. Jakarta. 